\title{
ANALISIS KESALAHAN JOSHI DALAM TEKS SAKUBUN MAHASISWA TAHUN MASUK 2016 PROGRAM STUDI PENDIDIKAN BAHASA JEPANG UNIVERSITAS NEGERI PADANG
}

\author{
Masroini $^{1}$, Leni Marlina ${ }^{2}$, Hendri Zalman ${ }^{3}$ \\ Program Studi Pendidikan Bahasa Jepang ${ }^{1}$ (Jurusan Bahasa dan Sastra Inggris, Fakultas \\ Bahasa dan Seni, Universitas Negeri Padang) \\ Program Studi Pendidikan Bahasa Jepang ${ }^{2}$ (Jurusan Bahasa dan Sastra Inggris, Fakultas \\ Bahasa dan Seni, Universitas Negeri Padang) \\ Email Penulis : masroini65@yahoo.co.id
}

\section{Sejarah Artikel \\ Submit : 2019-8-08 \\ Diterima : 2019-8-19 \\ Diterbitkan : 2020-12-15}

\section{Kata Kunci:}

Analysis, Particle, Sakubun

\begin{abstract}
Abstrak
This research is motivated by difficulties of students in using joshi $\mathrm{o}$ in the teks sakubun. This study aims to determine the errors in the teks sakubun for college student class 2016 Japanese Language Education Studies Program State University of Padang. The Method of this research is qualitative with descriptive method. The source of the data from the answer sheet of sakubun. The respondents of this research were 29 people. Based on the result of joshi errors in the teks sakubun, it is know that joshi ni and no errors is the highest error with the percentace of $17,24 \%$ while the lowest error is in joshi to and mo with a percentace of $3,44 \%$.
\end{abstract}

\section{PENDAHULUAN}

Bahasa Jepang memiliki karakteristik yang unik. Keunikan yang pertama yaitu huruf terdiri dari 4 jenis yang digunakan secara bersamaan. Yang kedua adalah kelas kata yang mengalami perubahan bentuk mengikuti fungsinya di dalam kalima. Ketiga struktur dan pola/susunan kata yang membentuk frasa. Struktur frasanya dipengaruhi oleh kata yang membentuk frasa dan memiliki pola/susunan "Menerangkan-Diterangkan" (MD). , fungsi kalimat dapat mempengaruhi bentuk kata yang digunakan, misalnya: fungsi waktu, fungsi, positif-negatif, dan lain sebagainya. Kedua, kata-kata yang menjadi unsur pembentuk kalimat dihubungkan oleh joshi. terkait frasa dan kalimat, ada satu kelas kata yang memiliki keunikan tersendiri karena memiliki peran di frasa dan memiliki peran pula di kalimat, yaitu joshi.

Joshi merupakan kelas kata yang tidak dapat berdiri sendiri (fuzokugo). Sebagai salah satu unsur penting dalam pembentukan frasa dan kalimat bahasa Jepang, Joshi mempunyai jumlah dan fungsi yang beragam. Ada kalanya satu fungsi bisa dipenuhi oleh 1 (satu) atau lebih joshi, dan ada kalanya pula ada satu joshi yang memiliki 1 (satu) atau lebih fungsi tergantung pada kalimat yang

\footnotetext{
${ }^{1}$ Mahasiswa Prodi Pendidikan Bahasa Jepang FBS UNP lulus pada Juni 2019

2 Dosen Prodi Pendidikan Bahasa Jepang FBS UNP

${ }^{3}$ Dosen Prodi Pendidikan Bahasa Jepang FBS UNP
} 
dibentuknya. Joshi dalam bahasa Jepang mempunyai jumlah dan fungsi yang beragam sehingga menyebabkan pembelajar bahasa Jepang penutur Indonesia bisa melakukan berbagai kesalahan dalam menggunakan joshi.

erdasarkan uraian diatas maka penulis merasa perlu mengadakan penelitian yang berjudul analisis kesalahan joshi dalam teks sakubun mahasiswa tahun masuk 2016 Program Studi Pendidikan Bahasa Jepang Universitas Negeri Padang.

\section{METODE PENELITIAN}

Jenis penelitian ini adalah penelitian kualitatif. Penelitian kualitatif adalah penelitian yang datanya bukan berupa angka-angka dan tidak perlu diolah dengan metode statistik (Sutedi, 2009:23). Pada penelitian ini data yang diperoleh berupa hasil teks sakubun mahasiswa tahun masuk 2016 Program Studi Pendidikan Bahasa Jepang Universitas Negeri Padang.

Metode penelitian yang digunakan dalam penelitian ini adalah metode deskriptif. Penelitian deskriptif adalah berasal dari istilah bahasa Inggris to describe yang berarti memaparkan atau menggambarkan, menjabarkan, suatu hal, misalnya keadaan, kondisi, situasi, peristiwa, kegiatan dan lain-lain (Arikunto, 2010:3).

\section{HASIL DAN PEMBAHASAN}

Data yăng dianalisis dalam penelitian ini adalah kesalahan joshi dalam teks sakubun mahasiswa tahun masuk 2016 Program studi Pendidikan Bahasa jepang Universitas Negeri Padang. Dalam penelitian ini, hanya terdapat kesalahan frasa terkait joshi dalam teks sakubun mahasiswa Program Studi Pendidikan Bahasa Jepang Universitas Negeri Padang tahun masuk 2016.

Berdasarkan analisis data, didapat beberapa temuan mengenai bentuk, jenis, dan penyebab kesalahan joshi dalam teks sakubun mahasiswa Program Studi Pendidikan Bahasa Jepang Universitas Negeri Padang tahun masuk 2016.

Table 1 Temuan Kesalahan Joshi Pada Teks Sakubun Mahasiswa Tahun Masuk 2016 Program Studi Pendidikan

\begin{tabular}{|c|c|c|c|c|c|c|}
\hline & & & Bahasa J & ang & & \\
\hline No & Kesala- & Frrekuensi & D. & Persentas & Kesalahan ( & \\
\hline NO. & han Joshi & & Sintaksis & Mistake & Kompetensi & Generalisasi \\
\hline 1. & $G a($ が $)$ & 2 & 6,89 & 11,11 & 6,89 & 0,0 \\
\hline 2. & Wo(を) & 4 & 13,79 & 22,22 & 13,79 & 0,0 \\
\hline 3. & To (と) & 1 & 3,44 & 5,55 & 0,0 & 6,89 \\
\hline 4. & $N i$ (に) & 5 & 17,24 & 27,78 & 17,24 & 0,0 \\
\hline 5. & $\operatorname{No}(の)$ & 5 & 17,24 & 27,78 & 17,24 & 0,0 \\
\hline 6. & Mo (も) & 1 & 6,89 & 5,55 & 0,0 & 3,48 \\
\hline & Total & 18 & & & 100 & \\
\hline
\end{tabular}

Sejalan dengan rumusan dan batasan masalah penelitian pada pembahasan akan dibahas mengenai : (1) Bentuk kesalahan sintaksis joshi(joshi) dalam teks sakubun; (2) Jenis kesalahan joshi(joshi) dalam teks sakubun; (3) Penyebab kesalahan joshi dalam teks sakubunmahasiswa Program Studi Pendidikan Bahasa 
Jepang Universitas Negeri Padang.

\section{a. Bentuk Kesalahan Sintaksis Joshi Dalam Teks Sakubun}

Bentuk kesalahan sintaksis joshi dalam teks sakubun dapat dilihat dari karangan mahasiswa Program Studi Pendidikan Bahasa Jepang Universitas Negeri Padang tahun masuk 2016. Berdasarkan kesalahan-kesalahan yang dibahas dalam analisis data, terdapat faktor-faktor yang mempengaruhi kesalahan sintaksis. Pertama, mahasiswa sulit menentukan joshi yang digunakan dalam sebuah kalimat atau frasa. Kedua, mahasiswa kurang memahami konsep penggunaan joshi yang sesuai dengan kaidah bahasa Jepang.

\section{b. Jenis Kesalahan Joshi Dalam Teks Sakubun}

Jenis kesalahan yang terdapat dalam penelitian ini adalah kekeliruan (mistake). Kesalahan kekeliruan (mistake) terjadi ketika seseorang pembelajar tidak secara konsisten melakukan penyimpangan dalam berbahasa. Kadang- kadang pembelajar dapat mempergunakan kaidah/norma yang benar tapi kadang- kadang mereka membuat kekeliruan dengan mempergunakan kaidah/norma dan bentukbentuk yang keliru. Kesalahan pembubuhan joshi ni (に) setelah kata isshoni ( いっしよに) yang diikuti oleh kata joshi wo (を)danyomimasu (よみます). Menurut aturan bahasa Jepang, tidak perlu dibubuhkan joshi wo (を). Hal ini menunjukkan mahasiswa kurang memahami fungsi joshi wo (を) yang tidak boleh digunakan setelah joshi ni (に).

\section{c. Penyebab Kesalahan Joshi Dalam Teks Sakubun}

Faktor penyebab kesalahan dalam penelitian ini ada dua penyebab, yaitu : faktor kompetensi dan generalisis. Pertama, penyebab kesalahan kompetensi pada joshi terjadi karena kekeliruan mahasiswa dalam penambahan joshi ga (が) yang sebetulnya tidak diperlukan. Pada kalimat tersebut, terdapat joshi ga (が) sesudah kata ichiban (いちばん) dan diikuti oleh kata suki (すき). Jika dilihat dari fungsi ga (が) sebagai joshi yang dipakai setelah nomina untuk menunjukkan bahwa nomina yang ada sebelumnya itu adalah subjek untuk menegaskan pernyataan dalam sebuah kalimat, mahasiswa kurang memahami fungsi joshi ga (が).

Kedua, penyebab kesalahan generalisasi pada joshi terjadi karena kekeliruan mahasiswa dalam menambahkan joshi no (の) setelah kata nоти (のむ) yang diikuti oleh kata kerja taberu (たべる). Seharusnya untuk menyambung dua kata kerja tidak digunakan joshi no (の) akan tetapi dengan pola kalimat te (て). Contohnya pada kalimat yang ditulis oleh mahasiswa yaitu "Ramadhan のげつに muslim のひとはのむとたべてもしていけません” jika diartikan ke dalam bahasa Indonesia berarti "dibulan ramadan orang muslim tidak boleh makan dan minum”. Dimana joshi to (と) digeneralisis dengan artian dan, padahal aturan dalam bahasa Jepang tidak demikian. Fungsi joshi to (と) Untuk menyatakan 
objek yang melakukan aktivitas bersama-sama dengan subjek dan menggabungkan beberapa nomina.

Penelitian mengenai kesalahan joshi dalam teks sakubun sudah pernah dilakukan oleh Sari (2013). Pada penelitian tersebut dinyatakan bahwa terdapat kesalahan penggunaan joshi wa dan joshi ga dalam teks sakubun mahasiswa. Perbedaan hasil penelitian tersebut dengan hasil penelitian ini dengan penelitian Sari yaitu terdapat 10 kesalahan penggunaan joshi wa dan 22 kesalahan penggunaan joshi ga dalam teks sakubun mahasiswa sedangkan hasil penelitian ini terdapat 6 kesalahan joshi, yaitu joshi ga, o, ni, to, no dan mo.

Pada penelitian yang dilakukan oleh Hodri (2018) diketahui dari hasil penelitian ditemukan bahwa kesalahan joshi yang sering dilakukan oleh mahasiswa adalah kesalahan joshi no, sedangkan penelitian ini kesalahan yang sering dilakukan adalah kesalahan joshi ni dan no.

Pada penelitian yang dilakukan oleh Wahyudin (2012) diketahui dari hasil penelitian ditemukan bahwa kesalahan berbahasa disebabkan oleh interferensi bahasa penutur.

\section{KESIMPULAN}

Berdasarkan pembahasan yang telah penulis lakukan tentang analisis kesalahan joshi pada teks sakubun mahasiswa tahun masuk 2016 program Studi Pendidikan / Bahasa Jepang Universitas Negeri Padang, penulis dapat menyimpulkan bahwa:

1. Bentuk kesalahan sintaksis joshi dalam teks sakubun pada penelitian ini ada 6 kesalahan joshi, yaitu: joshi ga, wo, ni, to, no dan mo.

2. Jenis kesalahan joshi dalam penelitian ini adalah mistake atau kesalahan yang dilakukan oleh mahasiswa yang tidak berlangsung secara terus menerus. Jumlah mistake dalam teks sakubun penelitian ini terdiri dari; joshi ga (が) sebanyak 2 kesalahan dengan persentase 11,11\%, joshi wo (を) sebanyak 4 kesalahan dengan persentase $22,22 \%$, joshi to (と) sebanyak 1 kesalahan dengan persentase kesalahan 5,55\%, joshi ni (に) sebanyak 5 kesalahan dengan persentase $22,78 \%$, joshi no(の) sebanyak 5 kesalahan dengan persentase $27,78 \%$, joshi mo(も) sebanyak 1 kesalahan dengan persentase $5,55 \%$.

3. Penyebab kesalahan joshi dalam penelitian ini adalah faktor kompetensi dan generalisasi. Penyebab kesalahan faktor kompetensi adalah kurangnya kemampuan yang dimiliki oleh mahasiswa dan kurangnya pengetahuan mengenai kaidah bahasa. Selanjutnya kesalahan faktor generalisasi adalah kebiasaan pembelajar bahasa menulis bentuk kata yang sama dalam bahasa yang sedang dipelajarinya misalnya dengan mengidentikkan suatu unsur bahasa seperti kata atau joshi tertentu dengan kata atau joshi lainnya. 


\section{REFERENSI}

Arikunto, Suharsimi. 2010. Prosedur Penelitian Suatu Pendekatan Praktek. Edisi Revisi Jakarta: Rineka Cipta.

Hodri, Muhamad. 2017. "Analisis Kesalahan Penggunaan Joshi pada sakubun Mahasiswa Semester 3”. Jurnal Undhiksa. Vol. 8(2): 35-43.

Sari, Yona Dwita. 2013. "Analisis Kesalahan Penggunaan Fungsi Joshi Wa DanGa Dalam Mata Kuliah Sakubun”. Jurnal UNRI. Vol 4(2): 1-7.

Sutedi, Dedi. 2003. Dasar- dasar Linguistik Bahasa Jepang. Bandung:Humaniora.

Wahyudin, Zida. 2012. “Analisis Kesalahan Berbahasa Dalam Tugas Sakubun”. Jurnal Parafrase Vol. 12(02):28-33. 